\title{
Camp literature. Introduction ${ }^{1}$
}

The term camp literature is usually applied within Polish studies to literature discussing German Nazi camps of various types, particularly those which are defined as concentration camps and/or death camps, and, though less often, Soviet camps, particularly forced labour camps, commonly referred to (both in Russian and Polish) as лагерь/tagier (gulags). Therefore, it covers one of the thematic varieties of writing. ${ }^{2}$ Literature is understood, in this case, as works with a dominant aesthetic function, or one in which that function plays a significant role, i.e. fiction, and the so-called fringe literature (quasi-literature), and, additionally, testimony literature, including personal document literature. The lines between those varieties of (broadly considered) literature are not always clear, sometimes quite variable. ${ }^{3}$

The criteria of time and place of a work's creation, and its authorship enables one to identify three areas within thus considered camp literature.

The first one is literature created in a camp. That would be camp literature in the most acute meaning of the term, possibly (though this term is somewhat

${ }^{*}$ Associate Professor; Chair of Polish Literature of the $20^{\text {th }}$ and $21^{\text {st }}$ Century, Institute of Polish Philology and Speech-Language Pathology, University of Łódź; arkadiuszmorawiec@poczta.fm.

${ }^{1}$ This article is an introduction understood twofold. Firstly, it includes terminological considerations regarding camp literature, and the scope of research defined by the term (fulfilled within literary science, and designed below), and, secondly, it precedes the series of articles, presented below, devoted to camp literature, collected under the uniform title The literature in/after concentration and death camps.

${ }^{2}$ The notion of camp/Lager/Gulag literature, and other related notions also exist in foreign literary sciences - vide, e.g. O. Gruenwald, "Yugoslav Camp Literature. Rediscovering the Ghost of a Nation's Past-Present-Future", Slavic Review, vol. 46 (1987), pp. 513-528; T. Taterka, Dante Deutsch. Studien zur Lagerliteratur, Erich Schmidt, Berlin 1999; В. Петелин, История русской литературы второй половины ХХ века (1953-1993), Центрполиграф, Москва 2013 (ch. Лагерная литература. Погружение во тьму в поисках света).

${ }^{3}$ Vide, e.g. K. Wyka, "Pogranicze powieści”, Twórczość 1946, col. 2, pp. 145-150; J. Jedlicki, "Dzieje doświadczone i dzieje zaświadczone", in: Dzieło literackie jako źródło historyczne, Z. Stefanowska and J. Sławiński (eds.), Czytelnik, Warsaw 1978, pp. 344-371; J. Leociak, "Literatura dokumentu osobistego jako źródło do badań nad zagładą Żydów. Rekonesans metodologiczny", Zagłada Żydów. Studia i Materiaty, issue 1 (2005), pp. 13-31; A. Morawiec, Literatura w lagrze, lager w literaturze. Fakt - temat-metafora, Wydawnictwo Wyższej Szkoły Humanistyczno-Ekonomicznej, Łódź 2009, pp. 13-18. 
awkward) literature of the camp ${ }^{4}$ but rather not literature in the camp ${ }^{5}$ as literature was also read in the camps. One should bear in mind, though, that the topic of the literature created in that special space was not always the camp reality. Despite that, considering its origins, its place of creation, it seems reasonable (and that is the general usage) to use for all its achievements the term camp literature. That type of literature was created by internees, yet one should not overlook the fact that camp functionaries had some share in it (e.g. Kurt Franz, the commandant of Treblinka, is considered the author of Treblinka's camp anthem, a song sung by prisoners; ${ }^{6}$ Johann Paul Kremer, another SS man, was the author of a journal written in Auschwitz). ${ }^{7}$

The second area (component) of camp literature is literature created outside a camp. When works were authored by former internees (or, possibly, former functionaries, which cannot be excluded altogether), one should discuss postcamp literature which, at the same time, is camp-themed literature. In the case of the authorship of persons who did not experience life in a camp, only the latter should be applied. Works which belong to literature created outside a camp, e.g. both Dzień $i$ noc by Leo Lipski created "after the camp", and Warkoczyk, whose author, Tadeusz Różewicz, had never experienced life in a Lager, ${ }^{8}$ are usually considered, similarly to literature created in a camp (in particular those achievements where the camp is the theme), using the term camp literature.

The third area would be literature regarding the near-camp areas. It includes works raising such issues and themes as, e.g. near-camp resistance (Dom pod Oświęcimiem by Tadeusz Hołuj), the fate of released/liberated internees, and often the related themes and motifs, such as the DP camp (Obóz Wszystkich Świętych by Tadeusz Nowakowski), and post-camp trauma (various works by Zofia Romanowiczowa), camp museum or a memory site in the place of a camp ( $W y$ cieczka do muzeum by Różewicz), hiding/wanted camp torturers (Doścignięty by Jan Dobraczyński). ${ }^{9}$

\footnotetext{
${ }^{4}$ M. K., "Literatura obozu", Gtos Demokratyczny 1946, issue 32, p. 5.
}

${ }_{5}^{5}$ M.M. Borwicz [Boruchowicz], Literatura w obozie, Wojewódzka Żydowska Komisja Historyczna w Krakowie, Krakow 1946.

${ }^{6}$ Vide E. Kopówka, Treblinka. Nigdy więcej, Muzeum Walki i Męczeństwa w Treblince, Muzeum Regionalne w Siedlcach, Treblinka-Siedlce 2002, pp. 23-24.

${ }^{7}$ J.P. Kremer, [Pamiętnik], foreword by J. Rawicz and introduction by J. Bezwińska, trans. J. Rawicz, Zeszyty Oświęcimskie, [col.] 13 (1971), pp. 29-115.

${ }^{8}$ L. Lipski, "Dzień i noc (na otwarcie kanału Wołga-Don)", in: ibid., Dzień i noc (Opowiadania), Instytut Literacki, Paris 1957, pp. 7-40; T. Różewicz, "Warkoczyk", in: ibid., Pięć poematów, Czytelnik, Warsaw 1950, p. 11.

${ }^{9}$ T. Hołuj, Dom pod Oświęcimiem. Sztuka w 4 aktach, Sztuka, Warsaw 1948; T. Nowakowski, Obóz Wszystkich Świętych, Libella, Paris 1957; Z. Romanowiczowa, Przejście przez Morze Czerwone, Libella, Paris 1960; T. Różewicz, "Wycieczka do muzeum”, in: ibid., Wycieczka do muzeum, Czytelnik, Warsaw 1966, pp. 11-22; J. Dobraczyński, Doścignięty, Pax, Warsaw 1967. The problems with terminology associated with what I referred to above as the near-camp theme were discussed by S. Buryła in the article "Lager - Literature - Zones of Silence" (included in this volume). 
Considering the meaning of the words literature and the camp, one could refer the term camp literature also to works discussing, e.g. boy scouts' camps. In such a case, camp literature would also include a youth novel entitled Czarne Stopy ${ }^{10}$ by Seweryna Szmaglewska. Within so broadly understood camp literature, which considers various meanings of the camp and camp [adjective] lexemes, ${ }^{11}$ there could also be included works discussing fitness camps, training camps, and, e.g. a socialist camp - if such has ever been written. If maybe training camps had played such a significant role in the life of Europe and the world as those referred to as concentration camps or camps bearing the object modifier death, the term camp literature would connote different things than it does today. Clearly such an extensive expansion of the meaning of the term camp literature is unfounded. Therefore, one could assume that Lidia Burska, the author of an extensive lexicon article regarding the domain of writing we are currently interested in, which undoubtedly, included within the fundamental compendium of Polish literary of the $20^{\text {th }}$ century, has modelled its perception and the way in which it is understood, was right in saying that

camp literature is thematically related to the writings devoted to the Second World War, and if it is separated, that is only because the experiences described by it are exceptional, incomparable to any other wartime experiences. ${ }^{12}$

Even if the above definition is applied by the researcher only to camp literature, it proves extremely narrow, primarily due to the fact that camp literature (not only Lager literature, i.e. applicable to German camps, but also Gulag literature, i.e. applicable to Soviet camps) was created even before WWII in various languages. From Polish literature, one might quote the 1930 "memoir from Sołówki" by Mieczysław Lenardowicz entitled $\mathrm{Na}$ wyspach tortur $i$ śmierci, ${ }^{13}$ and a series of reports by Jerzy Rogowicz about the concentration camp in Dachau printed six years later in Kurier Warszawski. ${ }^{14}$ The definition proposed by Burska, reflecting

Buryła is also the author of a valuable study entitled "Portret oprawcy" (in: ibid., Tematy (nie) opisane, Universitas, Krakow 2013, pp. 241-423).

${ }^{10}$ S. Szmaglewska, Czarne stopy, Śląsk, Katowice 1960.

${ }^{11}$ Vide Stownik języka polskiego PWN, M. Szymczak (ed.), PWN, Warsaw 1999, vol. 2, p. 400 (entry obóz).

${ }^{12}$ L. Burska, "Obozowa literatura", in: Stownik literatury polskiej XX wieku, A. Brodzka et al. (ed.), Ossolineum, Wrocław 1993, p. 740.

${ }^{13}$ M. Lenardowicz, Na wyspach tortur i śmierci. Pamiętnik z Solówek, Wojskowy Instytut Naukowo-Wydawniczy, Warsaw 1930. Eugeniusz Czaplejewicz in a book entitled Polska literatura tagrowa also mentioned a two-volume collection entitled Za kratami więzień i drutami obozów (wspomnienia i notatki więźniów ideowych z lat 1914-1921) published prior to the war, i.e. in 1927-1928 (ibid., Polska literatura łagrowa, PWN, Warsaw 1992, p. 42).

${ }^{14}$ J. Rogowicz, "W obozie koncentracyjnym", Kurier Warszawski 1936, issue 255 (evening issue), pp. 2-3; “Za co? Od jak dawna?”, issue 256 (evening issue), pp. 2-3; “«Wychowanie» przez obóz", issue 258, p. 6; "Wszerz i wzdłuż obozu”, issue 260 (evening issue), pp. 2-3; “《Korytarz» polski w obozie", issue 308 (evening issue), p. 2; "Jak ich żywią?", issue 314, p. 5; "Przyszłość obozu", issue 321 , pp. 7-8. 
the state of knowledge, or rather a general conviction, ${ }^{15}$ which was still applicable not so long ago, seems excessively narrow also because the type of camp the special paradigm of which are Nazi camps (best known by the Western world, then in Poland as well), had its original models and its literature.

I usually refer to the German Nazi camps, which operated in 1933-1945, neglecting political correctness, as German camps. When I apply the adjective Nazi, I do it for two reasons. Firstly, it is adequate in relation to camps which operated within the borders of the German Reich in the period prior to the outbreak of WWII, because the majority of the internees consisted of Germans, or at least citizens of the Reich. ${ }^{16}$ They certainly felt, and rightly so, to have been interned by the Nazis, not Germans. Then, the Poles, Russians, German Jews, and the representatives of other nations interned from the outbreak of WWII felt themselves to have been interned by the Germans, prisoners of the German state, not the NSDAP. Secondly, at the beginning of the $20^{\text {th }} \mathrm{c}$., German colonial forces (German, not imperial or Wilhelmian) performed a planned extermination of Herero and Nama tribes within the areas of today's Namibia. The survivors were interned in camps referred to then - by Germans - as Konzentrationslager. ${ }^{17}$ The internees were forced to do debilitating physical labour, they were starved, experimented upon, women were raped; mortality within those Lagers was extremely high. In this context, it is necessary to add that apart from the early German camps, there also existed at the turn of the $20^{\text {th }}$ century other camps, referred to as concentration camps or, sometimes, colonial concentration camps, i.e. Spanish camps in Cuba, American camps in the Philippines, and British camps in south Africa. In essence, those were hostage camps, extensively cruel, and bringing death to many of those interned there. ${ }^{18}$ (Evidently, when Hitler pointed out to the British that they were the original creators of concentration camps in relation to those created in the Third Reich, he was not much mistaken). Finally, there were the Russian, or rather Soviet, camps (the first of which should be defined as Bolshevik camps). I shall not retrace their origins to the quarry described by Thucydides, ${ }^{19}$ which was later turned by the Syracusans into

${ }^{15}$ Vide A. Morawiec, Literatura w lagrze..., pp. 29-129 (ch.: Polska literatura lagrowa. Prolog; "Więc moje pisanie do dopiero poczatek...”. Polska literatura lagrowa w okresie drugiej wojny światowej).

${ }^{16}$ Vide K. Dunin-Wąsowicz, Ruch oporu w hitlerowskich obozach koncentracyjnych 1933$1945,2^{\text {nd }}$ edition, Państwowe Wydawnictwo Naukowe, Warsaw 1983, p. 25; N. Wachsmann, Historia nazistowskich obozów koncentracyjnych, trans. M. Antosiewicz, Świat Książki, Warsaw 2016, pp. 226-229.

${ }^{17}$ Vide D. Olusoga, C.W. Erichsen, Zbrodnia Kajzera, trans. P. Tarczyński, Wielka Litera, Warsaw 2012, p. 465 (vide also ch. "Wyspa śmierci”, pp. 277-308).

${ }^{18}$ Vide A.J. Kamiński, Koszmar niewolnictwa. Obozy koncentracyjne od 1896 do dziś. Analiza, trans. H. Zarychta and the author, Przedświt, Warsaw 1990, pp. 33-37.

${ }^{19}$ Thucydides, Wojna peloponeska, trans., foreword and notes by K. Kumaniecki, Czytelnik, Warsaw 1988, pp. 456-458 (book VII). 
an exceptionally severe prison for Athenians, in which Mieczysław Jastrun saw the first concentration camp, ${ }^{20}$ to the concentration camps in Lithuania, ${ }^{21}$ where Russians grouped the Bar confederates, or the "terrible death camp for stubborn priests" 22 in Rochefort-sur-Mer in France, established in 1794, mentioned by Pawel Jasienica in Rozważania o wojnie domowej. American historians and literary scientists could raise in this context the issue of the "reservations" for Native Americans, and the most severe POW camp from the Civil War, i.e. Camp Sunter (Andersonville), in which over a dozen thousand people died mainly due to atrocious living conditions and related diseases. A literary commemoration of that is the Pulitzer award winning novel by MacKinlay Kantor entitled Andersonville. ${ }^{23}$

Soviet camps, within Western culture less paradigmatic than their Nazi counterparts (German: Lager; Polish: obóz, lager), though it was the Nazis that in many cases modelled the former, came to be known, not only in Poland, as gulags (Russian: лагерь, Polish: łagier). Thus, the term Gulag literature (Russian: лагерная литература, Polish: literatura lagrowa). It is convenient as it enables one, thanks to its phonetics (Polish and Russian $\boldsymbol{t} / \boldsymbol{\pi}$ vs. Polish and German $\boldsymbol{l}$ ), to separate the two areas of writing: literature applicable to Soviet camps, and literature discussing German (Nazi) camps (German: Lagerliteratur, Polish: literatura lagrowa). Whereas the generally used (incorrectly) division into camp literature and Gulag literature ${ }^{24}$ seems less useful, and, at the same time, somewhat blurring the reality as it suggests that Soviet gulags were something fundamentally or at least to a considerable extent different from the German Nazi camps known as concentration camps. In fact, one should rather notice the similarities between the German Lagers of 1933-1945 (immediate extermination camps were a separate phenomenon), and the initially Bolshevik and later Soviet gulags which existed from 1918. The first model (already Soviet) лагерь was established in 1923 in the Solovetsky Islands, ${ }^{25}$ ten years prior to the model camp in Dachau (Musterlager).

${ }^{20}$ M. Jastrun, Mit śródziemnomorski, Państwowy Instytut Wydawniczy, Warsaw 1962, pp. 13-14.

${ }^{21}$ J. Czapski, Na nieludzkiej ziemi, Czytelnik, Warsaw 1990, p. 134.

${ }^{22}$ P. Jasienica, Rozważania o wojnie domowej, Wydawnictwo Literackie, Krakow-Wrocław 1985 , p. 55. The author indicated, incorrectly, 1792 as the date of establishing the camp. Priests, over eight hundred in total, were interned on ships (once used for carrying slaves). Their planned deportation to Guyana came to no avail. Most of them died due to various diseases, exhaustion, and cruel treatment - vide Y. Blomme, Les prêtres déportés sur les pontons de Rochefort, Bordessoules, Saint-Jean-d'Angély 1994.

${ }^{23}$ M. Kantor, Andersonville, World, Cleveland 1955. Regarding the camp vide C. Gourley, The horrors of Andersonville. Life and death inside a civil war prison, Twenty-First Century Books, Minneapolis 2010.

${ }^{24}$ E.g.: "Camp and Gulag literatures" (S. Burkot, Literatura polska w latach 1939-1999, Państwowy Instytut Wydawniczy, Warsaw 2002, p. 106); "literature of concentration camps and «gulags»" (S. Sawicki, "Problematyka aksjologiczna w nauce o literaturze", in: Problemy teorii literatury, works selected by H. Markiewicz, series 4, Ossolineum, Wrocław 1998, p. 359).

${ }^{25}$ Vide A. Applebaum, Gułag, trans. J. Uchański, Świat Książki, Warsaw 2013, p. 49. 
From the very beginning, Soviet gulags were referred to as concentration camps (кониентрационные лагеря). That term was last used officially in 1934. Afterwards, though it sometimes happened before that, they were officially referred to as "correction through labour camps" (исправительно-трудовыле лагеря). ${ }^{26}$ In any case, I refer to both the literature discussing German (Nazi) camps, and the literature devoted to Soviet (communist) camps with the superordinate term camp literature, while whenever I need to specify the matter further, I refer to Lager literature or Gulag literature.

One ought to, of course, discuss both the similarities and the (indubitable) differences between Lagers and gulags. (That is a task for a historian). Not everyone concedes that gulags were concentration camps. That is due to the fact that, in general, the two most "famous types" of (Nazi) camps continue to be mistaken with one another: a concentration camp and a death camp (centre of immediate extermination). The former is often assigned the characteristics of the latter, due to the incorrect conviction that in all Nazi concentration camps people were murdered in their masses using gas, or that the basic purpose of such an institution was to exterminate the inmates. The Soviets, excluding the extensive executions (e.g. in Katyn), in which, in fact, German operating groups (SS-Einsatzgruppen) also specialised, in the camps what was preferred was "gradual" killing - through terror, starvation rations, and exhausting physical labour (an "exception" to the rule were the years 1937-1938, the period of the Great Purge, when people were also murdered during mass executions). ${ }^{27}$ In a similar way, i.e. by inflicting slow death (or rather not sudden), the Nazis (Germans) worked in concentration camps, particularly during the initial phase of their operations, and during the initial phase of WWII (more precisely: before the defeat at Stalingrad, after which prisoners were spared more - as a "workforce"). In order to inflict mass, and sudden, death, they established death camps (the first of those, Kulmhof, began operations in December 1941).

Former Gulag internees, whose testimonies had much difficulty in reaching the Western world, and who ached that their suffering, unlike the pain of the internees of German camps, was noticed by no one, indicated the similarities between both "systems", between, in short, Kolyma and Auschwitz. Anatol Krakowiecki wrote:

Two opposing poles, the same system. Smoke over Birkenau and smoke over the taiga. Instant, terrible death: gas! - slow rotting, and the flesh falling off of bones: scurvy! A red crematorium and a white one! [...] There multiply, there multiply lists, summaries, and analogies. [...] If Satan has wings, these are those wings - of the one and only Satan!"28

${ }^{26}$ Significantly enough, Rudolf Höss, the commandant of KL Auschwitz-Birkenau, mentioned "Russian concentration camps" (Autobiografia Rudolfa Hössa, komendanta obozu oświęcimskiego, trans. W. Grzymski, foreword F. Ryszka, notes edited by A. Pankowicz, Wydawnictwo Prawnicze, Warsaw 1990, p. 159).

${ }^{27}$ Vide A. Applebaum, Gutag, pp. 123-125.

${ }^{28}$ A. Krakowiecki, Ksiażka o Kotymie, Veritas, London 1950, p. 248. [English version translated from Polish] 
In the story by Varlam Shalamov entitled The Life of Engineer Kipreev, Kolyma was called Auschwitz without the ovens - "Колыма - это Освенцим без печей." 29

The best definition of a concentration camp I have ever found was one by a Nazi SS-Obersturmbannführer Dr Fritz Arlt, a subordinate of Hans Frank: "What do I think a concentration camp is? Exactly that what the name suggests: a camp in which there are concentrated people who in any way pose a threat to law and order." ${ }^{30}$ The first part of the expression, both ingenious and cynical, includes a dictionary definition, known in lexicology as semantic. Arlt was right: a concentration camp in its most basic meaning is an institution, the purpose of which is to isolate specific groups of people, often - as in Cuba, the Philippines, and in south Africa (during the Second Boer War) - leading to the death of a major part of them. In that sense, one could consider Second World War Jewish ghettos or PRL's isolation centres for internees in 1981-1982 (commonly known as isolation camps or camps for internees) as concentration camps. All of those possess their specific literatures, including artistic varieties thereof. That of the former, i.e. literature of the ghetto ${ }^{31}$ or ghetto literature, is so extensive, and, at the same time, so distinct ${ }^{32}$ that to include it within the term camp literature seems redundant (though it does not have to be). In the case of the latter, even though Andrzej Józef Kamiński referred to the places where Solidarity activists and other opposition activists were kept as concentration camps, ${ }^{33}$ it is customary to define it as the literature of the interned persons. ${ }^{34}$

Any attempt at introducing terminological order in this area of history and (history of) literature subject to ideological and political pressures would seem extremely difficult. (Initial work would rather fall on the historian than

${ }^{29}$ В. Шаламов, Собрание сочинений в шести томах, И.П. Сиротинская (ed.), Терра, Москва 2004, vol. 2 (Кольмские рассказы. Анна Ивановна: пьеса), p. 153. The Polish translator of the story destroyed that equation, as it would be difficult to consider the expression: "Kolyma - is a Stalinist special death gulag" as its equivalent (V. Shalamov, "Życie inżyniera Kipriejewa", in: ibid., Opowiadania kołymskie, trans. J. Baczyński, 3rd edition amended, Rebis, Poznań 2010, p. 608). $\mathrm{NB}$, it seems just as surprising that Baczyński would translate (thus euphemising) the Russian words лагерь, лагерный as Gulag, and Gulag [adjective], instead of camp, and camp [adjective].

${ }^{30}$ As cited in: L. Rees, Naziści. Ostrzėzenie historii, foreword I. Kershaw, trans. S. Kędzierski, Prószyński i S-ka, Warsaw 1998, p. 138. [English version translated from Polish].

${ }^{31}$ W. Bartoszewski, "Polskie judaica literackie w publikacjach konspiracyjnych lat 19391944", Twórczość 1962, issue 9, p. 48.

${ }^{32}$ Vide I. Maciejewska, "Getta doświadczenie w literaturze", in: Stownik literatury polskiej XX wieku, pp. 331-338.

${ }^{33}$ The author assigned the term a primary meaning, which functioned at the beginning of the $20^{\text {th }} \mathrm{c}$., yet he did so in a perversive manner, i.e. hyperbolically, politically engaged, to emphasise the similarity of the places of isolation (camps of the internees) with Soviet and Nazi camps (vide ibid., Koszmar niewolnictwa..., p. 109 note 115, p. 243).

${ }^{34}$ Vide K. Orman, "Twórczość literacka internowanych w czasie stanu wojennego (19811983)”, Acta Universitatis Lodziensis. Folia Historica, vol. 91 (2013), pp. 199-218. 
a literary scientist). In fact, there have always been problems with terminology. In Władysław Wójcik's memoir from 1939 entitled Bytem w piekle..., Buchenwald was defined as a concentration camp, though in one instance it was referred to it as an isolation camp. ${ }^{35}$ The author wrote:

Concentration camp!... A seemingly trivial name - while in fact... When describing hell, Dante used the strongest words to evoke terror in the face of the kingdom of the underworld. A concentration camp is a hundred times more terrifying an existence [...]... A concentration camp is an ordeal of the immortal human soul, it is human humiliation, debasement, thrusting into the role of an animal... ${ }^{36}$

Just a few years prior, a concentration camp still did not evoke such terror, or pose a particular reason for embarrassment. In 1934, Prof. Leon Kozłowski, Prime Minister and the minister of internal affairs of the Republic of Poland, when mentioning in Gazeta Polska the ordinance establishing isolation camps in Poland, and the German expression: "There must be order", he stated emphatically: "Concentration camps. Yes. Why? Because it is obvious [that] those eight years of work for the greatness of Poland [...] were not enough for some." ${ }^{37}$

In a monograph entitled Obóz odosobnienia w Berezie Kartuskiej 1934-1939, Wojciech Śleszyński wrote:

Existing publications include various terms: place of isolation, isolation camp, isolating camp, concentration camp. From the methodological point of view, all of them correspond to the discussed issue [i.e. the camp in Bereza Kartuska - note by A.M.] with the exception that, based on the experiences of WWII, the name concentration camp lost its initial meaning - of a place used for temporary concentration (internment) of political opponents, i.e. civilians, and has become the synonym of a death camp. Therefore, the author of this work rejected the use of the term altogether limiting himself to the first three terms. ${ }^{38}$

If, the author had not rejected that term, it would not serve today as a reason for outrage if one talked about Polish concentration camps. In fact, apart from the "Polish Sanation concentration camp in Bereza Kartuska"39 as Kamiński referred to it (the modifier Sanation seems to serve a similar role as the adjective Nazi added to the adjective German does) officially defined as a place of isolation, Poles established a whole archipelago of forced labour camps often referred to

${ }^{35}$ W. Wójcik, "Byłem w piekle... Lublinianin w niemieckim obozie koncentracyjnym w Buchenwaldzie", Głos Lubelski 1939, issues 225-227, 229-234, 236-239 (the term isolation camp [obóz odosobnienia] in issue 226 on p. 5).

${ }^{36} \mathrm{~W}$. Wójcik, "Byłem w piekle...", issue 226, p. 5.

37 "Miejsca odosobnienia. Oświadczenie premjera L. Kozłowskiego". Gazeta Polska, 1934, issue 168, p. 2.

${ }^{38}$ W. Śleszyński, Obóz odosobnienia w Berezie Kartuskiej 1934-1939, Benkowski, Białystok 2003, p. 11.

${ }^{39}$ A.J. Kamiński, Koszmar niewolnictwa ..., p. 46. 
(rather euphemistically, "suppressingly") as Stalinist or communist, the biggest of which was the Central Labour Camp in Jaworzno. Many of the labour camps, according to Zygmunt Woźniczka, were "in fact concentration camps where the living conditions and mortality, particularly in 1945, were not much different from those in Nazi concentration camps or Soviet gulags." ${ }^{40}$ Of course, to call German camps Polish concentration camps, not to mention death camps, is a manifestation of ill will or ignorance, or a mental shortcut, which even befell Zofia Nałkowska in Medallions. ${ }^{41}$ Going back to Śleszyński's remark, it would be prudent to make yet another reservation, i.e., as I have already indicated, a concentration camp (e.g. Ravensbrück or Mauthausen), and a death camp (e.g. Sobibór, or, actually, Sobibor) were not one and the same thing. Today, a concentration camp is understood not only as an isolating institution, but also one which was a device for torture, and a place of slave labour, in which, to various extents, people were killed through labour, torture, medical experiments, and, sometimes, through ad hoc executions. Those executions, however, were different than in camps defined (completely intentionally) as death camps or immediate extermination centres (in German, unofficially, as Vernichtungslager), like the already mentioned Sobibor, as well as Kulmhof, Treblinka, or Belzec (I shall retain their correct German names), to some extent Auschwitz, Lublin, and the so-called Janowska camp in Lviv (Zwangsarbeitslager Lemberg-Janowska).

German and Austrian proponents of Hitler (the latter are usually overlooked) ${ }^{42}$ displayed great inventiveness regarding the camps, which has resulted in additional study problems. They not only divided concentration camps (Konzentrationslager) into three categories (due to the degree of rigor), but they also created/separated

${ }^{40}$ Z. Woźniczka, "Centralny Obóz Pracy w Jaworznie na tle stalinowskiego systemu represji (1945-1950)", in: Obóz dwóch totalitaryzmów. Jaworzno 1943-1956. Materiały z konferencji naukowej „Historia martyrologii i obozów odosobnienia w Jaworznie w latach 1939-1956”, $2^{\text {nd }}$ edition amended, [vol. 1], K. Miroszewski, Z. Woźniczka (eds.), Muzeum Miasta Jaworzna, Jaworzno 2007, p. 94. Cf. also: "completely incorrect [...] is the differentiation [...] into «concentration camps» (Konzentrationslager) and «labour camps» (Arbeislager). [...] In reality, a «concentration camp» - Buchenwald, Dachau, Gross-Rosen etc. - was not actually a camp but an organisational unit within a system, a complex of camps consisting of the HQ in Buchenwald, Dachau etc., referred to as a «protective imprisonment camp» (Schutzhaftlager) and a larger number of «external camps» (Aussenlager), «kommandos», officially known as «labour camps» (Arbeitslager, AL). The final name was a reflection of the general Nazi tendency to mask things, and assign innocently sounding names" (A.J. Kamiński: Koszmar niewolnictwa ..., pp. 50-52).

${ }^{41}$ Nałkowska regrettably remarked about "Polish death camps" in a study entitled "Ludzie w Oświęcimiu" (Głos Ludu 1945, issue 157, p. 5). That term was established "for ever after" in an altered version of the text entitled "Dorośli i dzieci w Oświęcimiu", included in the Medallions collection (Czytelnik, Warsaw 1946).

${ }^{42}$ The Austrians included, e.g. Amon Göth, the commandant of the labour camp in Płaszów n. Krakow, turned in early 1944 into a concentration camp, Franz Stangl, commandant of the death camps in Sobibor and Treblinka, and Odilo Globocnik, who managed the extermination of Jews within Aktion Reinhardt. 
labour camps (Arbeitslager), penal camps (Straflager), educational labour camps (Arbeitserziehungslager), resettlement (Umsiedlungslager) and transitional (Durchgangslager) camps, hostage camps (Internierungslager), etc. The differences between them were not always clear. Sometimes two or more types of Lagers operated at the same location. For example, Auschwitz was initially a concentration camp, and later, simultaneously, a death camp. The area of the Gross-Rosen concentration camp included a separate barrack which housed an educational labour camp. The camp commonly referred to as Majdanek was called Kriegsgefangenenlager der Waffen SS Lublin (POW camp), later renamed to Konzentrationslager Lublin (later, the designation concentration camp disappeared from its name). The Lublin camp also fulfilled the function of a penal-transitional camp for the Polish rural population, as well as a death camp. Stutthof was, at first, a camp for civilian POWs, and it became a formal concentration camp two and a half years later. Sometimes, the line between a camp and a prison was also blurred. For example, Fort VII in Poznań has usually been defined as a prison, but sometimes also as a concentration camp. It is noteworthy that it was the first location where Germans (the Nazis) gassed people, so, actually, it was also (an experimental) death camp. ${ }^{43}$ The blurring of the line also applied to that between a concentration camp or a forced (slave) labour camp and a ghetto (examples being: the Theresienstadt ghetto-camp, the Janowska camp within the Lviv ghetto, and the ghettos in Warsaw and Łódź - in their final periods turned into labour camps). That is why some of the poems by Władysław Szlengel, written in or discussing the remains of the Warsaw Ghetto turned into a camp, belong just as much to the literature of the ghetto/ghetto literature, as to camp literature. ${ }^{44}$

Such terminological discussions seem inevitable, not only due to the special nature of the camps, actually not only of German and Soviet ones. Suffice to mention the Croat Jasenovac camp, established in 1941 by the fascist government of Ante Pavelić, at the same time fulfilled the function of a relocation camp, a concentration camp, and a death camp..$^{45}$ It was, apart from Auschwitz-Birkenau, the biggest centre for the extermination of Gipsies, a location of the torment of thousands of Serbs and Jews, as well as Croats and Muslims (Bosnians). Those discussions seem not unfounded also because one of the first (presumably) instances when the term camp literature was used in Polish refers to literature created during WWII in German POW camps. It was used, e.g. in the 1941 article written in an Oflag by Józef Słowiński entitled Dwa oblicza obozowej literatury. ${ }^{46}$ Literature discussing POW camps

${ }^{43}$ Vide A. Morawiec, “«Dezynfekcja». Literatura polska wobec eksterminacji osób psychicznie chorych", Przestrzenie Teorii, issue 27 (2017), pp. 271-272.

${ }^{44}$ W. Szlengel, Co czytatem umartym. Wiersze getta warszawskiego, I. Maciejewska (ed.), $2^{\text {nd }}$ edition amended. Państwowy Instytut Wydawniczy, Warsaw 1979.

${ }^{45}$ Vide P. Mojzes, Balkan genocides. Holocaust and ethnic cleansing in the twentieth century, Rowman \& Littlefield, Lanham 2011, pp. 56-58.

${ }^{46}$ J. Słotwiński, "Dwa oblicza obozowej literatury", Za drutami [Arnswalde Oflag] 1941, issue 1 , pp. 7-8. 
is rather extensive, and it includes both poems written at the camps, and works by former internees, e.g. the stories by Stanisław Zieliński, and Wspomnienia starobielskie by Józef Czapski. ${ }^{47}$ To avoid confusion, one could refer to those works as $P O W$ literature, as was done by the POW Eryk Zieliński in the article entitled Literatura jeniecka $(1940) .{ }^{48}$ Another issue is that the term prisoner of war also applied, particularly during WWII, and immediately after it, to the prisoners of Nazi concentration camps; today, however, the term mainly applies to soldiers. It is also important that during WWII some POWs were exterminated in their masses, also in the camps. The Soviets murdered (in Katyn and other locations) Polish POWs, previously held at (POW) camps. Soviet POWs died in their masses due to hunger and diseases in makeshift POW camps (particularly during the first phase of the German-Soviet war) ${ }^{49}$ they also died in concentration camps, and in immediate extermination camps, particularly if they were Jews or politruks. Therefore, the memoir of Lieutenant Alexander Pechersky, a Russian Jew, the leader of the uprising in Sobibor, entitled Uprising in Sobibor, ${ }^{50}$ belongs to POW literature, camp literature, and Holocaust literature. But one should not forget that apart from the type of internment, i.e. the camp, there also existed, so to speak, classical prisons, thus there also exists prison literature (for example: Krata by Pola Gojawiczyńska, Sto jedenaście dni letargu by Adam Grzymała-Siedlecki, Łagodne oko błękitu by Zofia Romanowiczowa). ${ }^{51}$ There were also, let us not forget about this, camps for DPs, i.e. displaced persons (which included many internees of concentration camps and former POWs), and the related, quite extensive, literature, ${ }^{52}$ as well as the, offering their own literature, exile locations. Internment camps are also noteworthy, which were rather diverse, known to some from their own experience, while for others, e.g. through the poetry of the martial law period in Poland, as well as from Jezioro Bodeńskie by Stanisław Dygat. ${ }^{53}$

${ }^{47}$ Drut opasat w krag. Antologia poezji jenieckiej z lat 1939-1945, selection, editing and introduction by R. Bednorz, Muzeum Martyrologii i Walki Jeńców Wojennych w Łambinowicach, Łambinowice 1984; S. Zieliński, Dno miski, Książka i Wiedza, Warsaw 1949; J. Czapski, Wspomnienia starobielskie, Oddział Kultury i Prasy 2. Korpusu, [place of publication missing] 1944. Vide also: P. Słowiński, "Polska elita w niemieckiej niewoli. O jeńcach i Oflagu II C Woldenberg w monografiach”, Język. Religia. Tożsamość 2016, issue 1, pp. 201-216.

${ }^{48}$ E. Zieliński, "Literatura jeniecka", Za drutami [Arnswalde Oflag] 1940, issue 8, pp. 6-7.

${ }^{49}$ A literary ripple of that was the famous poem by Wisława Szymborska entitled "Obóz głodowy pod Jasłem”, in: ibid., Sól. Państwowy Instytut Wydawniczy, Warsaw 1962, pp. 25-26.

${ }^{50}$ A. Peczorski, "Powstanie w Sobiborze", trans. A. Kubiak. Biuletyn Żydowskiego Instytutu Historycznego 1952, issue 1, pp. 3-45.

${ }^{51}$ P. Gojawiczyńska, Krata, Czytelnik, Warsaw 1945; A. Grzymała-Siedlecki, Sto jedenaście dni letargu (Wspomnienia z Pawiaka z lat 1942/1943), Wydawnictwo Literackie, Krakow 1965; Z. Romanowiczowa, Łagodne oko błękitu, Libella, Paris 1968.

${ }^{52}$ Vide article "DP camp - literary accounts of the life «in between». An invitation to the topic" by B. Krupa (included in this volume).

${ }^{53}$ Poezja stanu wojennego. Antologia wierszy, piosenek, kontrafaktur, parafraz i fraszek, A. Skoczek (ed.), Instytut Pamięci Narodowej - Komisja Ścigania Zbrodni przeciwko Narodowi Polskiemu, Dante, Krakow 2014; S. Dygat, Jezioro Bodeńskie, Wiedza, Warsaw 1946. 
(Incidentally, a superior comprehensive term enabling one to cover all the phenomena, literary varieties, and works mentioned above would be prison literature). ${ }^{54}$

If one limits the term camp literature, as has been generally done, to the literature devoted to concentration camps, and immediate extermination camps, possibly labour camps, POW camps, and internment camps, one would also need to consider among them - and it is high time to do so! - their incarnations other than the Soviet or Nazi ones. In a letter to his parents sent on 22 August 1941 from the Miranda de Ebro concentration camp (Campo de Concentración de Miranda de Ebro), Antoni Kępiński wrote: "Though camps are becoming increasingly fashionable throughout Europe, they do not present excessively interesting or nice sides. And Europe in the form of one big educational camp is not too encouraging a vision..." ${ }^{55}$ It seems that we not so much forgot as we have never realised the fact that camps, referred to one way or the other, always atrocious and destructive, were not the work of only Germans and Russians (Soviets), and that Polish camp literature also applies to other camps, as the future researcher of the survivor's syndrome called them in a letter to his parents, not only Spanish, but also domestic, e.g. the pre-WWII Bereza Kartuska or the post-WWII Jaworzno. ${ }^{56}$

When in 1978 the first Polish edition of Primo Levi's If This Is a Man, ${ }^{57}$ one of the major achievements of Lager literature and Holocaust literature, was published, one reviewer concluded that "[it] adds nothing new to our knowledge of the camps." 58 That opinion constituted a reflection as much of ignorance as the infamous conviction which existed for decades that Polish accounts about the camps were - let me quote the 1972 opinion of a well-known literary scientist - "the most numerous, and, which has a fundamental significance, the most important and the deepest." ${ }^{29}$ Today we know perfectly well that other literatures have also produced outstanding works both in terms of knowledge they offered and their artistic quality. In the case of Holocaust literature studies, it is actually inappropriate to debate that. In the case of camp literature, the matter seems less

${ }^{54}$ In the age of the influence/pressure of the widely understood post-colonial discourse, which consider the world as a prison, any attempt to conduct a terminological discussion regarding the notion seems doomed to fail.

${ }^{55}$ As cited in: A. Kępiński, Refleksje oświęcimskie, selection and introduction Z.J. Ryn, Wydawnictwo Literackie, Krakow 2005, p. 260.

${ }^{56}$ Vide Bereziacy, L. Pasternak (ed.), Książka i Wiedza, Warsaw 1965; A. Morawiec, "Campo de Concentración de Miranda de Ebro. Niedostrzeżony rozdział polskiej literatury obozowej”, in: W kręgu twórczości pisarzy emigracyjnych. Kontynuacje, Z. Andres (ed.), Wydawnictwo Uniwersytetu Rzeszowskiego, Rzeszów 2011, pp. 308-347; A. Morawiec, Jaworzno. Invisibility (included in this volume).

${ }^{57}$ P. Levi, Czy to jest człowiek, trans. H. Wiśniowska, Wydawnictwo Literackie, Krakow 1978.

${ }^{58}$ K. Fekecz, "Ocalić człowieka", Literatura na Świecie 1979, issue 8, p. 300.

${ }^{59}$ W. Wójcik, Opowiadania Tadeusza Borowskiego, Państwowe Zakłady Wydawnictw Szkolnych, Warsaw 1972, p. 27. 
obvious, particularly when one decides to use the term camp literature to cover not only works associated with Soviet or Nazi camps, but also texts devoted to the less known (to us) yet often equally atrocious camps: fascist (Spanish, Italian, Croatian, Japanese, Greek), or other (e.g. Serbian, known from the most recent war in Bosnia and Herzegovina). "To offer a complete listing of $20^{\text {th }}$-century KLs," said Kamiński, "would not be an easy task at least due to the fact that very few countries in the world have not stained themselves with, or have not been stained with them." ${ }^{60}$ If, as it turned out, Levi's recollections enriched our, i.e. Polish, perception of not only the Lager and Shoah, but also the related literature (including Polish, constituting for it their significant context), ${ }^{61}$ it would be worthwhile to finally view Polish camp literature (understood broadly in terms of its genre specificity, and in terms of the camp areas it discusses) in the light of other literatures of different origins presenting those camps which we already know and those which remain virtually unknown to us. First, one should, and I am writing this as a Polish studies specialist, identify what is read by Polish neo-philologists. ${ }^{62}$ It would be also worthwhile to, as it is has been done for some time now, present camp literature within the perspective of new discourses and tools, e.g. gender criticism and ecocriticism, or through the prism of corporeality, and mental trauma. ${ }^{63}$ No less revealing might prove, unwaveringly valid, bibliographic and archival records' studies which bring to light previously unnoticed clarifying phenomena, which had been unfairly considered as explained to a sufficient degree. The philological and hermeneutical studies of texts both known and completely new ones, which seek new modes of talking about the camp and Shoah experience are similarly fruitful. ${ }^{64}$ In any case, we are still far from - as argued by Dariusz Kulesza and Sławomir Buryła - achieving a complete image of Polish camp literature, ${ }^{65}$ let alone world literature.

${ }^{60}$ A.J. Kamiński, Koszmar niewolnictwa ..., p. 242.

${ }^{61}$ Vide P. Wolski, Tadeusz Borowski - Primo Levi. Prze-pisywanie literatury Holocaustu, Stowarzyszenie „Pro Cultura Litteraria”, Instytut Badań Literackich PAN, Warsaw 2013.

${ }^{62}$ Vide, e.g. K. Taczyńska, Dowcip trwajacy dwa i pół roku. Obraz Nagiej Wyspy w serbskim dyskursie literackim i historycznym końca XX i poczatku XXI wieku, DiG-La Rama, Warsaw-Bellerive-sur-Allier 2016.

${ }^{63}$ Vide the articles included herein: Women's hair in Lager narratives by B. Czarnecka, "Birdless Sky". On one of the topoi in Lager literature (and its fringes) by P. Krupiński, and Survival strategy. "The Death Brigade" by Leon Weliczker by B. Przymuszała.

${ }^{64}$ Vide the articles included herein: How to describe "the world of colossal absurd"? On the grotesque in Gulag literature by T. Sucharski, A flawed portrait. The image of Zofii Kossak in the accounts of former Birkenau female internees by J. Kowalska-Leder, Report and lament. Zalman Gradowski's notes from Auschwitz by K. Adamczyk, and Georges Didi-Huberman, "Écorces", Otto Dov Kulka, "Landscapes of the Metropolis of Death" - as Lager essays? Imagination and remembrance of the title formulations in relation to the formulation "anus mundi" by K. Kuczyńska-Koschany.

${ }^{65}$ Vide the articles included herein: Polish camp literature. A few questions about a synthesis that is missing by D. Kulesza, and Lager - Literature - Zones of Silence by S. Buryła. 


\section{Bibliography}

Applebaum Anne, Gułag, trans. Jakub Uchański, Świat Książki, Warsaw 2013.

Autobiografia Rudolfa Hössa, komendanta obozu oświęcimskiego, trans. Wiesław Grzymski, foreword Franciszek Ryszka, notes edited by Andrzej Pankowicz, Wydawnictwo Prawnicze, Warsaw 1990 .

Bartoszewski Władysław, "Polskie judaica literackie w publikacjach konspiracyjnych lat 19391944", Twórczość 1962, issue 9, pp. 48-62.

Bereziacy, Leon Pasternak (ed.), Książka i Wiedza, Warsaw 1965.

Blomme Yves, Les prêtres déportés sur les pontons de Rochefort, Bordessoules, Saint-Jean-d'Angély 1994.

Borwicz [Boruchowicz] Michał Maksymilian, Literatura w obozie, Wojewódzka Żydowska Komisja Historyczna w Krakowie, Krakow 1946.

Burkot Stanisław, Literatura polska w latach 1939-1999, Państwowy Instytut Wydawniczy, Warsaw 2002.

Burska Lidia, “Obozowa literatura”, in: Stownik literatury polskiej XX wieku, A. Brodzka et al. (ed.), Ossolineum, Wrocław 1993, pp. 740-746.

Buryła Sławomir, Tematy (nie)opisane, Universitas, Krakow 2013, pp. 241-423.

Czaplejewicz Eugeniusz, Polska literatura łagrowa, PWN, Warsaw 1992.

Czapski Józef, Na nieludzkiej ziemi, Czytelnik, Warsaw 1990.

Czapski Józef, Wspomnienia starobielskie, Oddział Kultury i Prasy 2. Korpusu, [place of publication missing] 1944.

Dobraczyński Jan, Doścignięty, Pax, Warsaw 1967.

Drut opasat w krag. Antologia poezji jenieckiej z lat 1939-1945, selection, editing, and introduction by Róża Bednorz, Muzeum Martyrologii i Walki Jeńców Wojennych w Łambinowicach, Łambinowice 1984.

Dunin-Wąsowicz Krzysztof, Ruch oporu w hitlerowskich obozach koncentracyjnych 1933-1945, $2^{\text {nd }}$ edition, Państwowe Wydawnictwo Naukowe, Warsaw 1983.

Dygat Stanisław, Jezioro Bodeńskie, Wiedza, Warsaw 1946.

Fekecz Kazimiera, “Ocalić człowieka”, Literatura na Świecie 1979, issue 8, pp. 299-301.

Gojawiczyńska Pola, Krata, Czytelnik, Warsaw 1945.

Gourley Catherine, The horrors of Andersonville. Life and death inside a civil war prison, Twenty-First Century Books, Minneapolis 2010.

Gruenwald, "Yugoslav Camp Literature. Rediscovering the Ghost of a Nation's Past-PresentFuture", Slavic Review, vol. 46 (1987), pp. 513-528.

Grzymała-Siedlecki Adam, Sto jedenaście dni letargu (Wspomnienia z Pawiaka z lat 1942/1943), Wydawnictwo Literackie, Krakow 1965.

Hołuj Tadeusz, Dom pod Oświęcimiem. Sztuka w 4 aktach, Sztuka, Warsaw 1948.

Jasienica Paweł, Rozważania o wojnie domowej, Wydawnictwo Literackie, Krakow-Wrocław 1985. Jastrun Mieczysław, Mit śródziemnomorski, Państwowy Instytut Wydawniczy, Warsaw 1962.

Jedlicki Jerzy, "Dzieje doświadczone i dzieje zaświadczone", in: Dzieło literackie jako źródło historyczne, Zofia Stefanowska and Janusz Sławiński, Czytelnik, Warsaw 1978, pp. 344-371.

Kamiński Andrzej Józef, Koszmar niewolnictwa. Obozy koncentracyjne od 1896 do dziś. Analiza, trans. Halina Zarychta and the author, Przedświt, Warsaw 1990.

Kantor MacKinlay, Andersonville, World, Cleveland 1955.

Kępiński Antoni, Refleksje oświęcimskie, selection and introduction Zdzisław Jan Ryn, Wydawnictwo Literackie, Krakow 2005.

Kopówka Edward, Treblinka. Nigdy więcej, Muzeum Walki i Męczeństwa w Treblince, Muzeum Regionalne w Siedlcach, Treblinka-Siedlce 2002. 
Krakowiecki Anatol, Ksiązka o Kolymie, Veritas, London 1950.

Kremer Johan Paul, [Pamiętnik], foreword by Jerzy Rawicz and introduction by Jadwiga Bezwińska, trans. Jerzy Rawicz, Zeszyty Oświęcimskie, [col.] 13 (1971), pp. 29-115.

Lenardowicz Mieczysław, Na wyspach tortur i śmierci. Pamiętnik z Sołówek, Wojskowy Instytut Naukowo-Wydawniczy, Warsaw 1930.

Leociak Jacek, "Literatura dokumentu osobistego jako źródło do badań nad zagładą Żydów. Rekonesans metodologiczny”, Zagłada Żydów. Studia i Materiały 2005, issue 1, pp. 13-31.

Levi Primo, Czy to jest człowiek, trans. Halszka Wiśniowska, Wydawnictwo Literackie, Krakow 1978.

Lipski Leo, "Dzień i noc (na otwarcie kanału Wołga-Don)", in: ibid., Dzień i noc (Opowiadania), Instytut Literacki, Paris 1957, pp. 7-40.

M. K., "Literatura obozu”, Głos Demokratyczny 1946, issue 32, p. 5.

Maciejewska Irena, "Getta doświadczenie w literaturze”, in: Stownik literatury polskiej XX wieku, A. Brodzka et al. (ed.), Ossolineum, Wrocław 1993, pp. 331-338.

"Miejsca odosobnienia. Oświadczenie premjera L. Kozłowskiego". Gazeta Polska 1934, issue 168, p. 2.

Mojzes Paul, Balkan genocides. Holocaust and ethnic cleansing in the twentieth century, Rowman \& Littlefield, Lanham 2011.

Morawiec Arkadiusz, "Campo de Concentración de Miranda de Ebro. Niedostrzeżony rozdział polskiej literatury obozowej”, in: W kręgu twórczości pisarzy emigracyjnych. Kontynuacje, Zbigniew Andres (ed.), Wydawnictwo Uniwersytetu Rzeszowskiego, Rzeszów 2011, pp. 308-347.

Morawiec Arkadiusz, "«Dezynfekcja». Literatura polska wobec eksterminacji osób psychicznie chorych", Przestrzenie Teorii, issue 27 (2017), pp. 261-295.

Morawiec Arkadiusz, Literatura $w$ lagrze, lager $w$ literaturze. Fakt-temat-metafora, Wydawnictwo Wyższej Szkoły Humanistyczno-Ekonomicznej, Łódź 2009.

Nałkowska Zofia, "Dorośli i dzieci w Oświęcimiu”, in: ibid., Medaliony, Czytelnik, Warsaw 1946, pp. $79-88$,

Nałkowska Zofia, “Ludzie w Oświęcimiu”, Głos Ludu 1945, issue 157, p. 5.

Nowakowski Tadeusz, Obóz Wszystkich Świętych, Libella, Paris 1957.

Olusoga David, Erichsen Casper W., Zbrodnia Kajzera, trans. Piotr Tarczyński, Wielka Litera, Warsaw 2012.

Orman Kamila, "Twórczość literacka internowanych w czasie stanu wojennego (1981-1983)", Acta Universitatis Lodziensis. Folia Historica, vol. 91 (2013), pp. 199-218.

Peczorski A[leksandr], Powstanie w Sobiborze, trans. Anna Kubiak. Biuletyn Żydowskiego Instytutu Historycznego 1952, issue 1, pp. 3-45.

Петелин Виктор, История русской литературы второй половины ХХ века (1953-1993), Центрполиграф, Москва 2013.

Poezja stanu wojennego. Antologia wierszy, piosenek, kontrafaktur, parafraz i fraszek, A. Skoczek (ed.), Instytut Pamięci Narodowej - Komisja Ścigania Zbrodni przeciwko Narodowi Polskiemu, Dante, Krakow 2014.

Rees Lawrence, Naziści. Ostrzeżenie historii, foreword by Ian Kershaw, trans. Sławomir Królak, Prószyński i S-ka, Warsaw 1998.

Rogowicz Jerzy, "W obozie koncentracyjnym”, Kurier Warszawski 1936, issue 255 (evening issue), pp. 2-3; "Za co? Od jak dawna?", issue 256 (evening issue), pp. 2-3; "«Wychowanie» przez obóz", issue 258, p. 6; "Wszerz i wzdłuż obozu”, issue 260 (evening issue), pp. 2-3; "«Korytarz» polski w obozie", issue 308 (evening issue), p. 2; "Jak ich żywią?", issue 314, p. 5; "Przyszłość obozu", issue 321, pp. 7-8.

Romanowiczowa Zofia, Łagodne oko błękitu, Libella, Paris 1968.

Romanowiczowa Zofia, Przejście przez Morze Czerwone, Libella, Paris 1960.

Różewicz Tadeusz, "Warkoczyk”, in: ibid., Pięć poematów, Czytelnik, Warsaw 1950, p. 11. 
Różewicz Tadeusz, "Wycieczka do muzeum”, in: ibid., Wycieczka do muzeum, Czytelnik, Warsaw 1966, pp. 11-22.

Sawicki Stefan, "Problematyka aksjologiczna w nauce o literaturze", in: Problemy teorii literatury, works selected by Henryk Markiewicz, series 4, Ossolineum, Wrocław 1998, pp. 355-366.

Shalamov Varlam, "Życie inżyniera Kipriejewa”, in: ibid., Opowiadania kołymskie, trans. Juliusz Baczyński, 3rd edition amended, Rebis, Poznań 2010, pp. 606-619.

Шаламов Варлам, Житие инженера Кипреева, w: tenże, Собрание сочинений в шести томах, Ирина П. Сиротинская (еd.), Терра, Москва 2004, vol. 2 (Колылские рассказы. Анна Ивановна: пьеса), pp. 152-165.

Słotwiński Józef, "Dwa oblicza obozowej literatury”, Za drutami [Arnswalde Oflag] 1941, issue 1, pp. 7-8.

Słowiński Przemysław, "Polska elita w niemieckiej niewoli. O jeńcach i Oflagu II C Woldenberg w monografiach", Język. Religia. Tożsamość 2016, issue 1, pp. 201-216.

Słownik języka polskiego PWN, Mieczysław Szymczak (ed.), PWN, Warsaw 1999, vol. 2.

Szlengel Władysław, Co czytałem umarłym. Wiersze getta warszawskiego, Irena Maciejewska (ed.), $2^{\text {nd }}$ edition amended., Państwowy Instytut Wydawniczy, Warsaw 1979.

Szmaglewska Seweryna, Czarne stopy, Śląsk, Katowice 1960.

Szymborska Wisława, “Obóz głodowy pod Jasłem”, in: ibid., Sól. Państwowy Instytut Wydawniczy, Warsaw 1962, pp. 25-26.

Śleszyński Wojciech, Obóz odosobnienia w Berezie Kartuskiej 1934-1939, Benkowski, Białystok 2003.

Taczyńska Katarzyna, Dowcip trwający dwa i pót roku. Obraz Nagiej Wyspy w serbskim dyskursie literackim i historycznym końca XX i początku XXI wieku, DiG-La Rama, Warsaw-Bellerive -sur-Allier 2016.

Taterka Thomas, Dante Deutsch. Studien zur Lagerliteratur, Erich Schmidt, Berlin 1999.

Thucydides, Wojna peloponeska, trans., foreword and notes by Kazimierz Kumaniecki, Czytelnik, Warsaw 1988.

Wachsmann Nikolaus, Historia nazistowskich obozów koncentracyjnych, trans. Maciej Antosiewicz, Świat Książki, Warsaw 2016.

Wójcik Władysław, "Byłem w piekle... Lublinianin w niemieckim obozie koncentracyjnym w Buchenwaldzie", Gtos Lubelski 1939, issues 225-227, 229-234, 236-239.

Wójcik Włodzimierz, Opowiadania Tadeusza Borowskiego, Państwowe Zakłady Wydawnictw Szkolnych, Warsaw 1972.

Wolski Paweł, Tadeusz Borowski - Primo Levi. Prze-pisywanie literatury Holocaustu, Stowarzyszenie „Pro Cultura Litteraria”, Instytut Badań Literackich PAN, Warsaw 2013.

Woźniczka Zygmunt, "Centralny Obóz Pracy w Jaworznie na tle stalinowskiego systemu represji (1945-1950)", in: Obóz dwóch totalitaryzmów. Jaworzno 1943-1956. Materiaty z konferencji naukowej „Historia martyrologii i obozów odosobnienia w Jaworznie w latach 1939-1956”, $2^{\text {nd }}$ edition amended, [vol. 1], Kazimierz Miroszewski, Zygmunt Woźniczka (eds.), Muzeum Miasta Jaworzna, Jaworzno 2007, pp. 87-113.

Wyka Kazimierz, "Pogranicze powieści”, Twórczość 1946, col. 2, pp. 145-150.

Za kratami więzień i drutami obozów (wspomnienia i notatki więźniów ideowych z lat 1914-1921), vol. 1-2, collected and edited by Wacław Lipiński [et al.], Komitet Organizacyjny Zjazdu b. Więźniów Ideowych, Warsaw 1927-1928.

Zieliński E[ryk], "Literatura jeniecka", Za drutami [Arnswalde Oflag] 1940, issue 8, pp. 6-7.

Zieliński Stanisław, Dno miski, Książka i Wiedza, Warsaw 1949. 


\section{Camp literature. Introduction}

(Summary)

This article includes a terminological discussion regarding the notion of camp literature. Within Polish literary science, it is usually applied to literature raising the topic of German Nazi camps, particularly concentration camps and death camps, and, though less often, to Soviet camps, particularly forced labour camps. Yet the definition has proved to be excessively narrow. It should also cover, previously less studied, works of Polish literature regarding, i.a. the Polish concentration camp in Bereza Kartuska, the communist labour camps established in post-WWII Poland, and the Spanish concentration camp in Miranda de Ebro. The notion camp literature could also be applied to works devoted to internment camps, POW camps, or even ghettoes.

Key words: Camp literature; definition; concentration camp; labour camp, death camp, internment camp; POW camp, ghetto 